\title{
Acquisition of Real Estate by means of the Contract of Sale Based on Albanian Legislation
}

\author{
Irena Lavdari , PhD Candidate
}

The European University of Tirana

Faculty of Law, ilavdari@yahoo.com

\section{Doi:10.5901/ajis.2013.v2n9p554}

\begin{abstract}
The contract of sale is one of the most useful contracts in the civil area by which are achieved the majority of commercial and legal-civil activities. The contracts of sale bear a special importance in relation to the socio-economical and political issues that are characteristic of national and international developments. Today they are considered to be an undeniable incentive for the economical initiatives of anyone without taking in consideration the fact that they might be Albanian or foreign citizens, public or private juridical person. A double economic function is achieved due to the contract of sale. On one hand the circulation of goods or in general of the rights and on the other hand the circulation of money. The contract of sale in many cases has caused many problems which stand at the roots of conflicts that should be dealt with and that require solutions in different legal ways.In this sense, because of the characteristics of the contract, it is very important the detailed analysis of it in order to make known the particular nature of the legal contract of sale as a juridical action, the elements of the contract of sale, its characteristics, the conditions of its validity, the settlement, the end and withdrawal from the contract. As far as the contracts of sales are concerned, the Albanian Civil Code foresees only two kinds of contracts of sales, basically the sale of real estates article 750 and the sale of property on bail in article 746. Referring to the kinds of the contracts of sales the business world consistently establishes new ones. Since contract of sale and its kinds are similar and numerous, it is inevitable that they may merge between them and other contracts that deal with the property, therefore the study of these contracts and the problems deriving from them in relation to different institutions of right referring to national and international transactions is very important.
\end{abstract}

Keywords: contract, side, sale, will, property, rights, obligation

\section{The Basis and Evolution of the Contractual Right in Albania}

Albania has been part of the Bizantine Empire for a long time. During the V-XII A.C. the economical, political and social organisation has preserved the same characteristics and traits that have been present during Roman rule due to the fact that the Bizantine rule in Albania lasted about 1000 years (Wilkes, 2005, p. 49-54). The feudal period is the first stage of the establishment of the first state of Albania in the XII century. In this period, special importance was given to various contracts such as: selling, renting, ordering, giving, etc. The increase of the civil circulation was preceded by an increase of the function and importance of notary. The notaries drafted testaments, contracts of sale, of real and personal property as well as other papers which based on law were supposed to be made by notarial act (The history of the Albanian state and that of Right in Albania,2011, p.115). In the medieval cities of Albania there were a considerable number of notaries particularly in Durrës who were organised in guilds (Oliver Jean Schmitt, 2007, p. 397-424). During the XIV century a well prepared organisation was applied to the contractual relations and from this period are preserved a number of contracts that testify a well developed technique of the drafting of these kind of legal papers. After the declaration of Independence and the establishment for the first time of a real Albanian State, the creation and riconstruction of the public institutions by approving laws on that purposebecame necessary. Although the Ismail Qemali's government made some changes and legal regulations, in some aspects it left in power the laws which were used during the Otoman invasion until the approval of the new laws. In 1912 until 1919 the right of obligations in Albania was regulated from Mexhele that recognised as the sources of the results of obligations of the contract, the cause of damage and enrichment without good cause. Among the main contracts were the selling, giving, use of borrowed money, warranty, pledge, deposit, order etc (Semini, 2006, p. 36). The juridicial regime of land until the year 1925 continued to be that of the Otoman Empire, which was regulated by the new law of lands of the year 1856. (Pulaha Selami, "The Feudal Ownership in the Albanian Properties, XV-XVI, Tirana, The Science Academy of PRA. History Inst., 1988). 
The Civil Code of The Albanian Kingdom of the year 1929 was a novelty for the reality of the Albanian state and society. There was no doubt that foreign rights particularly French, Italian and to a certain degree German and Swiss would inspire the Albanian Legislation to ratify in its acts the equality of the citizens, the emancipation of property over land and the freedom for participation in economical activities. This orientation would lay down the belonging of the Albanian civil right in the Roman-Germanic family, by completely separating it from the Otoman right. The same tradition continued even in the Code of Trade of the year 1932. Despite the fact that it was supported by the most advanced legislations of the time, the changes that occurred in Albania after the second World War, with the establishment of the so-called "popular regime", would bring its abrogation as well as legal, social and economical regress. After the year 1945 the civil legislation has been totally poor and disorganised. This period until the year 1990 can be considered a period of regress as far as the evolution of the right of property and conractual relations are concerned. The laws and decrees (Decree no. 2083, date 6.7.1955 "On Property") that were approved during this period considerably weakened and limited the private property. This one was restricted only about personal property, particularly those that belonged to the individual. Furthermore, the regulation and the role of contracts during this period suffers a continuous weakening. Private property on land, forests, grasslands etc. disappeared completely in 1966 when the agricultural co-operatives and public enterprise were spread all over the country. These steps were consolidated furthermore and all land was declared state property by the constitution of 1976. As a result of the process of passing from private to state property, there was no contractuar relation or real legal actions on property. A similar system, but in which the politics and ideology were displayed openly, was preserved in the Civil Code of 1981.

The Civil Code of 1981 provides that "The main source of the initiation of obligations in the Popular Socialist Republic of Albania are the acts of the planification of the socialist economy from the institutions in charge" (Article 140 of the Civil Code 1981). As mentioned above, the main source in contractual relations is not the conformity of ideas between the parties involved but the obligation to meet the requirements of the economic plans decided by the Popular Socialist Republic of Albania.

As far as the signing of individual contracts is concerned, they can "sign contracts to accomplish their meterial and cultural needs as well as for taking of benefits from owning their personal properties", (Article 14). What is characteristic about this period is the fact that the legislation for the execution of juridical-civil duties was present but what lacked was the real and effective possibility to execute these duties.

\section{The Comprehension of the Contract of Sale Based on Albanian Legislation}

The contract of sale is the most common legal means in civil circulation. The main legal and commercial activities of different subjects in the conditions of free enterprise are provided basically in the form of the contract. The definition of the contract is provided in the Civil Code specifically in the article 659 according to which "the contract is a legal act based on which one or two parties build, change or end a legal relation". The contract has two functions which are clearly recognizable among them. The contract is one way of gaining property and other real prerogatives. "The contract is also one of the sources of duties, therefore an instrument by means of which is acquired the right on the obligations of the others", (Dollani, " A series of lectures about the Comparative Civil Right", UET, 2010). In the Civil Code the contract of sale is regulated in the Heading II, the First Chapter, specifically in the Article 705 in which it is ratified that: "The Contract of Sale has as its main objective the passing of ownership over an object or the passing of a prerogative after the payment of a particular fee". The contract of sale is two-sided and rewarded. It is a consensual contract which means it is valid from the moment when the parties reach an agreement. In some cases the law requires the contract of sale to be formal and to be registered.

\section{The Elements of the Contract of Sale}

The contract or the legal action has its own elements which are those essential features that make its existence and validity necessary. The absence of one of them renders the contract or legal act invalid. The element in an obligatory legal term are: the subjects, the object, the content, which are the same even for the contract of sale.

The subjects of the contract of sale are the parties of the contract of sale. Typical examples are individuals, legal persons who can be native or foreigners, as well as the state (Semini,2006, p22). The parties in this contract are known as the seller and the buyer. The primary condition for the subjects that take part in the contract of sale is that they should have the ability to perform. According to the Article 6 of the Civil Code " An individual at the age of eighteen has complete ability to perform and can therefore have the opportunity to gain rights and take responsibility over civil duties. Article 709 of the Civil Code defines subjects that are excluded from the opportunity to buy directly, by the help of another person or 
in an auction, the properties of those who manage or protect by law, of a contract or appointment from state institutions. Here we take into consideration the caretakers, depositors, legal representatives etc, who are in charge of administering or protecting the properties. Similarly are excluded the persons who are officially in charge of selling by obligatory execution, only for the category of those objects that they sell, a category that includes the judicial bailiffs, the customers employees, the financial police, the forest rangers, the auctions' organisers, the financial employees that take part in the commisions of the evaluations of the objects that are definitely to be sold etc.

The judges, prosecutors, bailiiffs, notaries and lawyers cannot be buyers for the objects that are under their judgement in the court of law where they take part or exercise their duties. In the last paragraph of the article 709 of the Civil Code it is provided an exclusion. The judges, prosecutors, notaries can be presented as buyers only in those cases in which they are co-proprietors over something that is object of judgement in the Court of Law where they work.

As far as the contract of sale is concerned, its object can be everything that takes part in the civil circulation and that can be alienated without any legal restrictions, being it personal property or real property. Objective for the contract of sale can also be the objects with limited circulation, but as always by the permission of competent state institutions or based on legal procedures that are previously defined. For instance, the lands for building within the yellow lines of the cities, the agricultural lands, energetic and water sources, social and cultural objects etc, as well as the rights related to them. (Semini,2006, p22). It is provided by law for the first time in the Civil Code in the article 705 that object for the contract of sale can be not only things but rights as well. "The contract of sale has as its object the passing of the ownership of an object or the passing of a right towards the payment of a fee." Regarding the rights, the Civil Code does not specifically mention what kind of rights can be object of the contract of sale. However, based on practice and on the previous civil code (The Civil Code of the year 1929, articles 1470-1474), among the rights that can be object of sale can be mentioned: the right of inheritance, the right of use, invention, the right of using an object, the right of taking benefits from its profits, a right that is under the process of judgement but that has not been given the final verdict etc. Object of the contract of sale can also be a possession or a future right, that doesn't exist or that is not materialised at the moment of the signing of the contract, but it is foreseen by the parties concerned to be created in the future. According to the article 706 of the civil Code, the gaining of the ownership is done as soon as the possession or the right to be sold is established and starts to exist physically.

\section{The Rights and the Obligations of the Contract of Sale}

The sale is a two-sided contract and as such provides obligations for both parties. The whole sequence of rights and obligations of the seller and buyer make the content of the contract of sale (Semini, 2006, p. 10-12). Undoubtedly, the most important legal consequence of the contract of sale is the passing of ownership from seller to buyer. In order to accomplish this duty the seller has to be the owner of the object. The specification of the moment of passing the right of ownership in the contract of sale is particularly important. This importance has to do with the fact that from the moment of passing the right of ownership, the seller seizes to be the proprietor of the possession and at that precise time the buyer takes that position. A considerable number of legal consequences derive from this. Therefore, from that very moment the buyer can take his possession from any source. In addition, the risk of damage or that of being lost accidentally it's the seller's responsibility. Another duty of the seller is to deliver the possession to the buyer. According to article 711 of the Civil Code, the seller has to hand in the possession in exactly the same condition they were at the moment in which the contract was signed. The seller has the duty to hand in all the accessories as well as the profits accumulated from the possession since the moment when the contract was signed until the moment of its delivery. Moreover, the seller has to hand in all the documents that prove the right of ownership to the buyer so that he will have full competence over them. Another obligation that the seller has according to article 719 of the Civil Code is that he/she must guarantee the buyer about the non-existance of a third party that can claim the possession. This obligation is also called a guarantee for eviction (Semini, 2006, p. 40). Not only is the seller obliged to hand in the possessions that are object of the contract to the seller so that he can use them as he wishes, but also to guarantee from the very beginning that the possessions are of good quality and without any kind of flows. The quality of the sold possessions must fulfill the conditions in the contract even in those cases in which the conditions are not stated it must comply with the common conditions of their use (article $715 / 2)$.

As far as the obligations of the buyer in the contract of sale are concerned, it is the buyer that has the duty to pay the price for the sale which is an obligation that derives from the nature of the contract of sale. (Articles 730-739 of the Civil Code). In the contract it is usually defined not only the price but also the time and the way of payment. The price should be payed based on the conditions defined in the contract. When the time of the delivery of the price is not specified in the contract then it will be assumed that the money should be payed at the same time the possession is 
delivered (article 732 of the Civil Code). Whereas the place of payment if not specified in the contract would be paid in the premises where the seller performs his/her activity (article 448 of the Civil Code).

About the obligations that occur from the contract of sale, the buyer is not only obliged to pay the price but also to take delivery of the possessions, accept them at the time, place and in the way specified by the contract. If these are not specified in the contract there will be practised the common rules about deadline, place and the way for the accomplishment of the duties (Article 456-464 of the Civil Code). The article 734 of the Civil Code specifies the duties of the buyers to perform every necessary action in order to take delivery of the possessions or to allow the seller to deliver the possession. If the buyer does not accept the possession at the right time it means that he/she is not meeting the obligations that derive from the contract and as a consequence has to take responsibility for that. Not only when the buyer does not pay the price but also when he/she does not take delivery of the possession, the seller has the right to ask the buyer to pay the price and to accept the possession as well as to award damages because of the delay. When the buyer is late in taking delivery of the possession, the responsibility for the accidental loss will fall upon him/her because the buyer has the duty to pay the price and to award damages to the seller. Actually, if the buyer is late to take delivery of the possession, the possession is lost or accidentaly damaged, then the buyer has civil responsibility to award damages and to pay the price if this one is not paid in anticipation. In case it is specified in the agreement between the parties that the buyer must define the shape, size and characteristics of the possession but this one does not do that at the right time or within a reasonable limit of time after taking the order by the seller, then this right is passed to the seller who does the specification mentioned above on its own. After doing this the seller must notify the buyer and give him/her a reasonable deadline to decide if he/she agrees with the specifications done by the seller (Article 753 of the Civil Code). When the buyer has no complain after receiving the notification and the deadline decided by the seller is terminated, then the description made by the seller would be considered obligatory for the buyer. This means that from that moment the buyer has the responsibility to take delivery of the possession without having the right to drive back the possession by using the excuse of not specifying the conditions of the possession. As far as the rights and duties between the parties are concerned, it is the Judicial Court of Law in Tirana that has stated its position in the decision No.3917 date 13.05.2001.

\begin{abstract}
"The contracts define the rights and obligations among the parties concerned. Based on the content of the contract the plaintiff is obliged to meet the conditions specified in the contract, meanwhile the accused has the duty to make the monthly payment based on the deadlines stated in the contracts. "The user has these rights and obligations: to make the monthly payment according to the prices and fees in power...In those cases in which the deadline is not respected the default interest would be exercised. When the duty has not been payed even after the termination of the deadline, the plaintiff has the right to address his case to the court of law in order to solve its case."
\end{abstract}

In the article 698 of the Civil Code it is stated that: "In contracts with mutual duties, when one of the parties does not meet its own duties, the other contractual party can ask for the fulfillment of the conditions of the contract or the end of this one despite awarding damages". Under these conditions, the court of law decides if the claim of the plaintiff towards the accused party about the obligation to meet their duties is fair and should or not accepted.

This decision taken by the Judicial Court of Law in Tirana makes evident one more time that the parties in the contract must obey to their rights and duties that derive from the signing of this contract. One-sided disobedience or disrespect from one of the parties can result in the annulment of the contract as well as a request to award damages under the court of law.

\title{
5. The Annulment of the Contract of Sale
}

Albanian legislation makes it clear the distinction between the nullifying of the contract and its annulment. In the case of the nullifying of the contract it is important the presence of some necessary conditions, the lack of which brings the nullifying of the contract. Therefore, the article 663 of the Civil Code, defines that the essential conditions for the existence of the contract are: the consent of the party that takes the responsibility of the duties, the legal case upon which the duty is based, the object that makes the content of the contract and its right form required by law. The contract is considered absolutely invalid when one of the essential conditions mentioned above is missing.

As far as the contract of sale is concerned, in its annulment contribute the same rules as in other kinds of contracts. The annulment of the contract of sale is done as a result of not meeting of the criterias of the two classical forms which are, the annulment of the contract by legal means and its annulment by not using the legal means. The annulment by the use of legal means, the party that is not responsible for not accomplishing the duties can ask the 
accomplishment of it by using legal means or the annulment of the contract. In both cases the party has the right to require the award damaging (Article 698 of the Civil Code). It is specified in the Civil Code when the parties taking part in the contract of sale (the seller and buyer) have the right to anull it (Article 724-737). The same attitude is seen even in the Colleges of the High Courts of Law in the decision No.10, date 24.3.2004.

\begin{abstract}
"In a wider view, if in the contract of sale signed between the parties is defined that, under particular conditions, one of the parties will have the right to annul the contract one-sidedly (as it is specified in article 13.3 of the contract), the court of law that analyses the conflict has no right to order the signing of the contract in anticipation. The order to sign the contract for a second time is possible only by the verdict of the court of law to solve the case in essence."
\end{abstract}

\title{
6. The Consequences of the Annulment of the Contract
}

As a rule, the main consequence that derive from the annulment of the contract of sale is the returning of the parties in the initial position that was before the contract of sale was made. Actually, the seller has to take back the price as well as all the payment or expenses paid by the buyer while this one has to return the possession. Based on the responsibility of not meeting the demands, the parties can profit even the award of damages. In the Article 741 of the Civil Code are stated the cases when the contract of sale can be annuled, which apply to both the seller and buyer. In the contracts of sale when the possession is partly delivered, in case of not meeting the duties concerning the delivery by one party, then this is considered an important issue which will allow the other party to demand the annulment of the contract but only for that delivery. In the same contracts, when the act of not meeting the demands of a delivery causes the other party the convinction that the action would be repeated even in the future deliveries, then the damaged party has the right to demand the annulment of the contract for the future deliveries, something which must be made within a reasonable deadline. In the situation above in which the annulment of the contract is demanded by the buyer for one delivery, this one has the right of annulment of the previous or future deliveries if the result of this interdependence is not the achievement of the aim decided by the parties involved in the contract. In case of the annulment of the contract, the seller is obliged to return the money paid for the price, expenses and legally made fees to the buyer, whereas in case of the annulment of the contract by the buyer, this one must return the possession to the seller if it has not been lost or destroyed as a result of its flaws or characteristics (The Article 742 of the Civil Code). If from the moment of the signing of the contract until the moment of its annulment the value of the possession has decreased, then the seller is obliged to return the complete price to the buyer. If this decrease is a result of the misuse of the possession by the buyer and not as a result of the normal consumption, then the seller has the right to demand a reduction to the price that was previously stated in the contract that is related to the benefits if the buyer, according to the article 744 of the Civil Code.

\section{The Interpretation of the Contract of Sale according to the Albanian Legislation}

After the agreement is reached and the contract is signed, both parties have the obligation to meet the duties that derive from it. However, it often happens that one of the parties does not meet its duties by causing disagreements as a result. These disagreements can be solved by the courts of law, arbitration, negotiations or by involving a mediator. In this case, the need arises to interpret the text of the contract if the parties do not agree about the content of a particular part in it. It is also possible that the price is not clearly specified in the contract, but is just made clear that the price paid must be in conformity with the "price of the market". The parties can disagree about what the price of market implies. Is this the price of market when the contract was signed or when the disagreement is caused? Is this the price of market in the country of the seller or in that of the buyer? Such cases of disagreements indispensably require the interpretation of the contract. In the case of the interpretation of the contract, the court of law (or another institution that makes the interpretation), always takes into consideration some general principles, such as the principle of honesty, reasonability, and good faith (Article 682 of the Civil Code). In case of suspicion, the contract or its conditions are interpreted in the way in which some effect may result and not in the way that would have no effect whatsoever over the parties involved (Article 683 of the Civil Code).

Another rule followed by the court of law during the interpretation of the contract is the one in which the interpretation is not in favour of the party that has compiled the contract (Semini, Tirana, 2006, p.65). In the contracts compiled by hand, it often happens that one of the parties compiles particular parts of the contract. In such cases, the interpretation is made against the party that has compiled the unclear part. The parties can predict that in case of disagreements about the meaning of the contractual dispositions, then a third party must interpret them. In case when one of the contractual parties is a trade company, it will not be exercised the meaning based on the country where the 
contract is signed but that of the country where the company has the headquarters (Article 684 of the Civil Code). In the standard contracts compiled by one of the parties, the conditions that are in favour of the party that has prepared the contract but against the other party are not going to have any kind of effect, despite the cases when this is stated clearly in the contract (Article 684 of the Civil Code).

\section{The Characteristics of the Contract of Sale}

The Albanian Civil Code has stated a number of novelties and changes about the contract of sale in the articles 705-756, that make known its characteristics. The contract of sale is a legal action made towards payment. On the contrary, when the parties sign a contract of sale withot having the real intention of paying the price specified in the contract than we would be dealing with a worthless legal action (fictitious or simulated), (Article 684 of the Civil Code). The contract of sale is a contract decided by consensus (Maho, 2009, p 35- 36), which is considered signed in the moment in which the parties agree without following any kind of form. This is the general rule because when the object of this contract are real estates, despite being decided by consensus it also becomes formal. The contract of sale is a two-sided contract because the rights and the obligations of this contract are reciprocal (Maho, 2009, p 35- 36). This means that in front of the right of one party stands the obligation of the other party. Therefore, in front of the right of the buyer to take delivery and become the owner of the possession stands the duty of the seller to deliver the possession. As far as the form of the contract of sale is concerned, it can be said that it is formal. When the object of the contract of sale is real estate the contract of sale takes formal features (Maho, 2009, $p$ 35- 36). This means that the reciprocal agreement must be made by a noterial act whereas the registration in the Office of the Registration of Real Estates is not a cause for annulment any more. (The Unifying decision of the Joined Colleges of the High Court of Justice, No. 1 date 06.01.2009). Another characteristic of the contract of sale is also its real form in case of possession sold in types or series. Despite the compilation and the signing of the contract, as well as the agreement reached between the parties, for these possessions there is no legal consequence until the possession that is object of the contract is not delivered yet (Semini,2006, p. 107).

\section{Conclusions and Recommandations}

The contract of sale is one of the most common contracts in the civil circulation, by which most of the civil, legal acts are made. The Civil Code has put some rigid conditions about the specified commercial transactions and for the specification of the rights and obligations between the parties in an unchangeable way. Although in some cases this practise can be appropriate, special attention must be paid to the legislation which imposes restrictive conditions in personal interactions. In general, the commercial actors wish to be free to decide on their own about the degree of risk they are ready to undertake. By preparing the conditions of commercial transactions in advance, the incentive to find creative ways to make agreements between parties can be discouraged in a considerable amount for the business world.

\section{References}

The Civil Code of the Republic of Albania, approved by the law No. 7805, date 29.07.1994, changed by the law No.8536, date 18.10.1999 and No. 878, date 3.05.2001

The Civil Code of the Popular Socialist Party of Albania, approved by the law No. 6340, date 26.06.1981

The Civil Code of the year 1929, papirus, 2010

Law- No. 7843, date 13.07.1994 "About the registration of the real estates"

Decree no. 2083, date 6.7.1955 " About the property "

The Unified Decision of the Joint Colleges of the Supreme Court, No. 1 date 06.01.2009

The Unified Decision of the Joint Colleges of the Supreme Court No. 10, date 24.03.2004

The decision of the Judicial Court of Law Tirana No. 3917 date 13.05.2001

Dollani Nada, " A series of lectures on the comparative civil right ", EUT, 2010

Maho Besnik, " The gaining of ownership on real estates ", EUT - Press, Tirana, 2009

Pulaha Selami, " The Feudal Ownership in Albanian Properties, XV - XVI century, Tirana, The Science Academy of the PRA, The Institution of History, 1988.

Oliver Jean Schmitt, " The Venedict Arberia, 1392-149 ", Nature, Tirana, 2007

The History of the Albanian State and the State of Right in Albania, Luarasi, Tirana 2011

Wilkes John "The Illirus", Bacchus, Tirana, 2005

Semini Mariana, "The Right of Obligations and of the Contracts", the Particular Part, Scanderbeg books, Tirana, 2010

Semini Mariana, " The Right of Obligations and that of Contracts", the General Part, Scanderbeg books, Tirana, 2010 